\title{
Fertilizer optimization for hybrid sunflower under irrigated condition
}

\section{ADITYA KUMAR AND V.V. KRISHNAMURTHI}

Received : 21.07.2015; Revised : 30.10.2015; Accepted : 14.11.2015

MEMBERS OF RESEARCH FORUM:

Corresponding author : ADITYA KUMAR, Department of Soil Science and Agricultural Chemistry, Tamil Nadu Agricultural University, COIMBATORE (T.N.) INDIA

Email: aadi.bhu@gmail.com

Co-authors :

V.V. KRISHNAMURTHI, Department of Soil Science and Agricultural Chemistry, Tamil Nadu Agricultural University, COIMBATORE (T.N.) INDIA

\section{Summary}

This study was undertaken to optimize macronutrient requirement of hybrid sunflower for harvesting maximum yield and oil content in irrigated condition. For this purpose a field experiment was conducted at Oilseed Research Station, Tindivanam, Tamil Nadu Agricultural University. Experiment comprised of macronutrient treatments consisted of five levels of nitrogen $\left(0,30,60,90\right.$ and $\left.120 \mathrm{~kg} \mathrm{~N} \mathrm{ha}^{-1}\right)$, four levels of phosphorus $\left(0,30,60\right.$ and $90 \mathrm{~kg} \mathrm{P}_{2} \mathrm{O}_{5}$ $\left.\mathrm{ha}^{-1}\right)$ and four levels of potassium $\left(0,30,60\right.$ and $\left.90 \mathrm{~kg} \mathrm{~K}_{2} \mathrm{O} \mathrm{ha}^{-1}\right)$. Increasing levels of $\mathrm{N}, \mathrm{P}, \mathrm{K}$ increased yield, yield components and oil content. Maximum seed yield $\left(1170 \mathrm{~kg} \mathrm{ha}^{-1}\right)$ and oil content (41.4\%) was recorded with NPK @ 120:90:90 kg ha-1 $\left(\mathrm{T}_{7}\right)$. Treatment $\mathrm{T}_{7}$ proved its superiority by recording 12.5 per cent increased seed yield and 13.1 per cent increased oil yield over recommended dose of fertilizers $\left(\mathrm{T}_{10}\right)$ i.e. NPK @ 60:90:60 kg ha-1. Hence NPK @ 120:90:90 $\mathrm{kg} \mathrm{ha}^{-1}\left(\mathrm{~T}_{7}\right)$ was observed most suitable to obtain maximum quantitative and qualitative yield of hybrid sunflower under irrigated condition.

Key words : Fertilizer optimization, Hybrid sunflower, Macronutrient management, Nutrient uptake

How to cite this article : Kumar, Aditya and Krishnamurthi, V.V. (2015). Fertilizer optimization for hybrid sunflower under irrigated condition. Asian J. Soil Sci., 10(2) : 259-262. 